Article

\title{
Weak or Strong Sustainability in Rural Land Use Planning? Assessing Two Case Studies through Multi-Criteria Analysis
}

\author{
Itziar Barinaga-Rementeria ${ }^{1, *(D)}$ and Iker Etxano $2,3,4$ (D) \\ 1 Department of Accounting and Finance I, University of Basque Country (UPV/EHU), \\ 01006 Vitoria-Gasteiz, Spain \\ 2 Department of Applied Economics I, University of Basque Country (UPV/EHU), 48940 Leioa, Spain; \\ iker.etxano@ehu.eus \\ 3 HEGOA, Institute of Development Studies and International Cooperation, University of Basque \\ Country (UPV/EHU), 48015 Bilbao, Spain \\ 4 EKOPOL Research Group, University of Basque Country (UPV/EHU), 48940 Leioa, Spain \\ * Correspondence: itziar.barinagarementeria@ehu.eus; Tel.: +34-945-01-4372
}

Received: 6 February 2020; Accepted: 17 March 2020; Published: 19 March 2020

\begin{abstract}
This paper addresses the debate regarding weak versus strong sustainability in the field of rural land use planning. Both concepts correspond to opposing paradigms on sustainability and both their fundamentals of economic roots and comparative analyses from a theoretical point of view enjoy a contrasting trajectory. However, their inclusion in land use planning has been an issue not sufficiently studied despite their relevance in the field of local development and sustainability. The aim of this study is to shed light on this gap by exploring the assessment of the degree of sustainability in rural land use planning. To this end, two case studies involving forestry in the Basque Country (Spain) have been analyzed based on a multi-criteria analysis technique. As a result, we have observed the importance of setting thresholds in the valuations of the criteria, as well as the effect of varying such thresholds above the compensability degree.
\end{abstract}

Keywords: weak sustainability; strong sustainability; multi-criteria analysis; NAIADE; rural land use planning; forestry

\section{Introduction}

The debate on the definition and scope of sustainability has a long history in terms of measurement and substitutability between different types of capital, with a distinction between strong sustainability and weak sustainability [1]. On the one hand, natural capital represents natural resources, which differs from human-made capital or manufactured capital, which is defined by its capacity for artificial reproduction, i.e., its capacity to be reproduced by human beings (e.g., machinery, infrastructures). The compensability and substitutability between natural capital and manufactured capital, the possibility that natural capital can be replaced by manufactured capital, and the effects that such a substitution can generate, have been the origin of the debate on the different degrees of sustainability.

In line with neoclassical economics and in accordance with the pioneering work of Solow [2], and later of Hartwick [3], weak sustainability is circumscribed in the paradigm of substitutability [1]. With the aim of ensuring that human welfare does not decrease, sustainability is defined in terms of the total utility offered by the sum of the accumulated capital-both the natural capital and the manufactured capital-assuming that the latter can replace the former. Sustainability therefore needs to maintain this capital-derived utility over time [4-7]. From this approach, therefore, it is assumed that all the values and functions, both those coming from the natural capital and the manufactured capital, 
can be quantified using a single scale, generally the monetary one, thus placing it in the framework of strong comparability [8]. Moreover, weak sustainability implies future uncertainty, both in terms of generational preferences and technological capacity [9].

On the other hand, strong sustainability argues that many of the values and services offered by nature cannot be replaced by human-made capital. This approach developed by ecological economics [10] argues that certain natural resources are limited and irreplaceable and therefore a minimum amount of different types of capital must be conserved [11-13]. In line with this, Pelenc and Ballet [14] argue that the natural capital has at least four characteristics that differentiate it from the manufactured capital: (i) the irreversibility of the natural capital [15]; (ii) natural capital is multifunctional, so it is unlikely that manufactured capital will act as an appropriate substitute for it; (iii) the lack of knowledge about the effects of the destruction of the natural capital, so it is appropriate to consider a precautionary principle; and (iv) ethical and justice issues with respect to future generations since an increase in future consumption is not an appropriate substitute for loss of natural capital. From this perspective, natural capital is neither compensable nor replaceable by manufactured capital, at least not in its entirety, and therefore cannot be perceived as a stock of resources. The fact that they are irreplaceable, places strong sustainability in the context of incomparability or weak comparability [8]. In addition, the existence of critical natural capital requires the setting of minimum conservation limits in the natural capital $[15,16]$. The critical threshold of a natural resource marks the level at which it loses its resilience, and falls into a position of irreversibility [17-19]. According to this principle, a certain amount of natural capital must be secured if the functions it offers to human welfare are to be maintained.

Recently, research in several areas has taken up the debate on strong sustainability and weak sustainability with a more practical vision: fisheries management [20]; urban heritage [21]; choice of technologies [22]; restoration of contaminated land [23]; public infrastructure [24]. However, spatial planning and land use planning are still insufficiently studied issues. In this respect, we must bear in mind that rural land is a limited and irreplaceable natural resource, and that under current conditions, it is difficult for the various functions and values it offers for human well-being to be replaced or even offered by technological advances. In view of this, land use planning should therefore consider the different values offered by rural soil ecosystems, together with the values coming from the socio-economic activities developed on that soil, and establish, if necessary, an acceptable degree of compensability.

So, the aim of this study is to shed light on this gap by: (i) approaching the conceptual framework for debate on the integration of sustainability in rural land use planning; and by (ii) exploring the assessment of the degree of sustainability in such a context. To this end, two case studies have been analyzed, applying a sustainability assessment tool based on a multi-criteria analysis technique. We have been able to analyze the issue of trade-offs among different dimensions of rural land use planning. With this aim, the paper is structured as follows. The next section addresses the issue of sustainability in rural land use planning. The third section describes the two case studies, and the methods and criteria employed for the analysis. In Section 4, we undertake the sustainability analysis and the results, and in Section 5, discussion is approached. Finally, in Section 6, we present the main conclusions drawn from the analysis of sustainability in rural land use planning.

\section{Integrating Sustainability in Rural Land Use Planning}

Sustainability is an issue that is intrinsically linked to land planning as a discipline that is approached under a systemic vision, as the territorial model is influenced by, among others, the physical environment and land uses, human settlements, and governance [25]. Planning strategies are also influenced by the different levels, hierarchies, principles, and scales in dispute [26], and for decisions to be sustainable, they must be based on multidimensional and multiscale analyses, assessment methods must be comprehensive and also include participatory processes [27]. In fact, given its multidimensional and multiscale nature, the integration of sustainability in land planning has been 
analyzed from multiple perspectives, such as: territorial plans that combine the socio-economic benefits with the environmental costs of regional growth [28]; the application of sustainability principles in the strategic environmental assessment of urban planning [29]; and the relationship between agricultural multifunctionality and sustainability in the framework of urban land uses [30].

In this multidimensional framework, however, rural land use planning has some particularities to take into account. First, the rural land and its main uses, agriculture and forestry, provide diverse values and functions for human well-being, such as the provision of food and raw materials, the maintenance of ecosystems, and the protection of species and water [31,32]. In the last few decades, land uses have changed widely in Europe [33]. These changes have affected natural land ecosystems, and the increasing urbanization of rural areas, intensive agriculture and forestry, and the abandonment of traditional land uses have had a significant impact on the landscape and biodiversity [34,35]. The increasing consumption of energy, water, and soil nutrients and the increase in plantations of exotic species are degrading soils and reducing biodiversity. This accelerates the natural processes of change and affects the provision of ecosystems goods and services to society [28,36-40].

Secondly, different change processes are taking place at the same time in rural land uses influencing each other [35]. Land science, as well as agricultural and forestry sciences, have spent considerable effort measuring, monitoring, and modeling such patterns [41-44]. Thus, the challenge is how to define and determine sustainable rural land use planning, i.e., how to integrate it comprehensively within socio-ecological systems where maintenance of both socio-economic activities and ecosystem services are pursued. From this multidimensional perspective, the question focuses on how to compare these different dimensions, and how to establish the possible compensations between them, if that is the case. For this purpose, the trade-offs between socio-economic benefits and environmental values must be considered $[28,45]$. The balance between those dimensions may determine the sustainability of the model, opening the debate about compensability and substitutability that can be allowed between different dimensions. These arguments lie on the basis of the distinction between strong sustainability and weak sustainability.

Last but not least, as noted, sustainable land use planning therefore requires multidimensional and multidisciplinary methods that can work with an integrating vision, whereby multiple disciplines work simultaneously [46]. In this sense, multi-criteria decision aid (MCDA) has emerged as an adequate support tool for decision-making on environmental management problems [8,47-49]. The multi-criteria analysis considers multiple dimensions of environmental issues, works with quantitative and qualitative information, considers the uncertainty in the future [50], and the complexity of environmental decisions [8]. Furthermore, by applying compensatory and non-compensatory multi-criteria analysis techniques, it is possible to evaluate various options and to identify trade-offs between different criteria [51]. Additionally, participatory multi-criteria methods have demonstrated their usefulness and applicability in land use planning [28,46,52-54].

\section{Case Studies and Methodology}

\subsection{Case Studies: Contetxt and Methods}

Two previously published case studies on rural land use planning have been used as references for this analysis. Both were carried out in the province of Gipuzkoa in the Basque Country (Spain), where forest policy in recent years has been the subject of debate between productivist positions and ecological visions. The first study was carried out in a Special Area of Conservation (SAC) integrated into the Natura 2000 Network (N2000), called Garate-Santa Barbara [55]. The second was held around the rural land of the municipality of Mutriku [56]. In both evaluations, the social multi-criteria evaluation (SMCE) methodological framework and the Novel Approach to Imprecise Assessment and Decision Environments (NAIADE) aggregation method were used, facilitating and giving robustness to the comparison between both cases. 
The SMCE is a tool to help decision-making in complex socio-ecological contexts $[48,57]$. Complex socio-ecological systems usually present immeasurable values and uncertainty, affecting heterogeneous groups of stakeholders with different interests, often in opposition to each other [8,58,59]. The SMCE is characterized by a multidisciplinary and participatory approach aimed at facilitating the search for solutions in natural resource management and sustainability, such as land use planning and territorial management [46,52]. (For an exhaustive review of both the methodological foundations of the SMCE and its applications, we recommend reviewing Munda [48,57], as well as the case studies analyzed).

Within MCDA framework, NAIADE belongs to the wide range family of outranking methods [60]. It was initially devised by Munda [61], and then technically developed [62]. It has been subsequently undertaken in multiple cases as support for decision-making, as for example, in forest planning (For further details, see Acosta and Corral [63]). Operationally, NAIADE makes comparisons of alternatives in pairs and, applying a mathematical algorithm, ranks the alternatives from the most suitable to the least suitable [62]. It simultaneously accepts criteria evaluated in different units of measurement, both quantitative and qualitative, this being a fundamental characteristic for carrying out multidimensional evaluations. NAIADE also allows a conflict analysis to be carried out by means of the degree of preference or rejection that the social actors involved have with regard to the different alternatives. Finally, NAIADE allows the model to introduce variations in the aggregation conditions in order to observe the effect of these variations on the final result.

\subsubsection{Case Study 1: Garate-Santa Barbara (GSB)}

GSB is a protected area in Gipuzkoa of approximately 142 hectares, which in 2003, was proposed to become part of the N2000, and since 2013, is an SAC of the aforementioned network. The reasons for this inclusion are the high value of native forest species found in the area, in particular, the cork oak (Quercus suber). In turn, GSB is valued as a recreational area because of its landscape made up of small farms and forests. However, in recent decades, the wine industry, dedicated to the production of a variety of white wine, txakoli, has grown significantly, becoming the main economic activity in the area. This has meant a change in land use, with more and more land being devoted to the cultivation of vineyards. The expansion of vineyards has led to a conflict between the defenders of native forests and the landowners, whose aim is to make the land profitable by growing vines for the production of txakoli. In recent years, there has been an increasing number of conflicts over different land uses within the N2000 [64], which shows the relevance of this case study.

The study by Etxano et al. [55] assesses different land uses, proposing scenarios in which the areas dedicated to vineyards and native forest vary. Different land use alternatives were defined according to the intensity of ecological value enhancement, also considering a system of additional payments in each of the possible scenarios (The payment system contemplates: (i) the compensations established by the provincial government for the reforestation with slow-growing tree species in N2000 areas, scenarios A21, A31, and A41; and (ii) additional compensation for lost profits and/or increased social welfare derived from the improvement of landscape characteristics and biodiversity, scenarios A22, A32, and A42). Table 1 shows the scenarios and land uses for each of them. 
Table 1. GSB land uses by scenario (in ha and as a \% of total).

\begin{tabular}{|c|c|c|c|c|c|}
\hline & Scenario 0 & Scenario 1 & Scenario 2 & Scenario 3 & Scenario 4 \\
\hline & $\begin{array}{c}\text { Status } \\
\text { Quo (\%) }\end{array}$ & $\begin{array}{c}\text { Business As } \\
\text { Usual (\%) }\end{array}$ & $\begin{array}{c}\text { Ecological Values } \\
\text { Strength Moderate (\%) }\end{array}$ & $\begin{array}{l}\text { Ecological Values } \\
\text { Strength High (\%) }\end{array}$ & $\begin{array}{c}\text { Ecological Values } \\
\text { Strength Maximum (\%) }\end{array}$ \\
\hline Alternatives & A01 & A11 & A22 & A32 & A41 \\
\hline Cork oak & 16.6 (11.6) & $16.6(11.6)$ & $21.1(14.7)$ & $28.3(19.8)$ & $51.7(36.1)$ \\
\hline $\begin{array}{l}\text { Indigenous } \\
\text { Woodland }\end{array}$ & $18.7(13.1)$ & $18.7(13.1)$ & $21.6(15.1)$ & $24.4(17.0)$ & $41.8(29.2)$ \\
\hline Heather land & $24.5(17.1)$ & $24.5(17.1)$ & $24.5(17.1)$ & $26.5(18.5)$ & $3.0(2.1)$ \\
\hline Forest plantation & $22.9(16.0)$ & $21.3(14.9)$ & $15.5(10.8)$ & $3.5(2.5)$ & $0.0(0.0)$ \\
\hline $\begin{array}{c}\text { Pasture, } \\
\text { allotments } \\
\text { and crops }\end{array}$ & $44.4(31.0)$ & $42.1(29.4)$ & 44.4 (31.0) & $44.4(31.0)$ & $34.1(23.8)$ \\
\hline Vineyard & $16.1(11.2)$ & 19.9 (13.9) & 16.1 (11.2) & 16.1 (11.2) & $12.6(8.8)$ \\
\hline
\end{tabular}

Source: adapted from [55]. Note: Scenarios 2,3, and 4 foresee a certain land use distribution (a certain area value and percentage) regardless of the compensation system.

The multi-criteria impact matrix shows the assessment obtained by each alternative for each of the different evaluation criteria (Table 2).

Table 2. Impact matrix for the case of GSB.

\begin{tabular}{|c|c|c|c|c|c|c|c|c|c|}
\hline Criteria & Unit & \multicolumn{8}{|c|}{ Alternatives } \\
\hline Landscape & Index & 10,527 & 10,590 & 11,092 & 11,092 & 11,928 & 11,928 & 15,073 & 15,073 \\
\hline Biodiversity & Index & 199 & 200 & 218 & 218 & 247 & 247 & 345 & 345 \\
\hline $\begin{array}{c}\text { Social } \\
\text { well-being }\end{array}$ & Million $€$ & 0 & 1.13 & 17.34 & 17.34 & 30.19 & 30.19 & 145.44 & 145.44 \\
\hline Cost & $€$ & 0 & 0 & 3583 & 29,361 & 9389 & 36,328 & 11,106 & 67,671 \\
\hline $\begin{array}{l}\text { Income } \\
\text { generation }\end{array}$ & $€$ & 115,838 & 134,616 & 118,222 & 144,000 & 121,936 & 148,875 & 98,547 & 155,111 \\
\hline Acceptability & ordinal & 5 & 6 & 3 & 2 & 4 & 1 & 5 & 3 \\
\hline
\end{tabular}

Based on the impact matrix, NAIADE calculates the different degrees of preference (index $\phi+$ ) and the degrees of rejection (index $\phi+$ ) (see Figure A1 in Appendix A). The index $\phi+$ reflects the ranking based on the number of criteria in favor of each alternative, and the index $\phi$-reflects the ranking based on the number of criteria against each alternative. The intersection between both indexes (the third column, Figure A1 in Appendix A), shows the ranking of alternatives from most to least suitable with respect to the assessment criteria used [62].

In this case, the best ranked alternative is A32 (" $\mathrm{F}$ " in Figure A1 in Appendix A), an alternative that offers high ecological values, combined with additional compensations (see "Intersection" in the third column of Figure A1 in Appendix A). In this alternative, the areas devoted to cork oak and indigenous woodland are significantly increased and those devoted to forest plantations are reduced. In the second position in the ranking is the alternative $\mathrm{A} 42\left({ }^{\prime \prime} \mathrm{H}^{\prime \prime}\right)$, which proposes a maximum ecological value enhancement through a greater surface area of cork oak and native forests and a reduction of the land destined to forest plantations and agricultural uses, also combined with additional compensations. 


\subsubsection{Case Study 2: Mutriku Municipality}

In the context of the elaboration of the Municipal Land-Use Plan of Mutriku, Etxano et al. [56] evaluated different alternatives of rural land use planning. Mutriku is a coastal municipality of Gipuzkoa, covering approximately 2700 hectares, where the Arno massif stands out, a SAC of the N2000 due to the great value of the Atlantic holm oak (Quercus ilex), which abounds. Due to its particular location, this municipality did not have the important industrial development of other municipalities in the area, maintaining until the mid-twentieth century an important agricultural activity and the traditional landscape of the rural mid-mountain areas of the Basque Country. However, in recent decades the relatively nearby industrial areas have led to the abandonment of agricultural activity, reducing the area of cultivated land and increasing the area occupied by coniferous forests to a large extent. This change in rural land use has meant a major change in the landscape, economy, and culture of the rural environment, as in many other locations on the Cantabrian coast [65].

Given the changes in rural land use in recent decades, three possible scenarios for the future were outlined: continuing with the current dynamics, promoting new agricultural activities, and promoting forests of native species. These scenarios are developed in five specific alternatives, showing different land uses for each (Scenario A1 would be continue with the current dynamics. The second scenario proposes a medium (A2a) or maximum (A2b) potentiation of agricultural activity, and conifer-based forestry policy and is divided into two alternatives that propose the medium potentiation (A3a) of forests of native species and the maximum potentiation (A3b) of this new forestry policy). Table 3 lists the areas of the different land uses for each alternative.

Table 3. Scenarios and rural land uses for Mutriku (in ha and as a \% of total).

\begin{tabular}{cccccc}
\hline Scenarios & Scenario 1 & \multicolumn{2}{c}{ Scenario 2 } & \multicolumn{2}{c}{ Scenario 3 } \\
\hline Alternatives & A1 & A2a & A2b & A3a & A3b \\
\hline Mixed Atlantic woodland & $290.26(10.7)$ & $290.26(10.7)$ & $290.26(10.7)$ & $590.16(21.7)$ & $667.96(24.5)$ \\
Holm oak woodland & $459.64(16.9)$ & $459.64(16.9)$ & $459.64(16.9)$ & $459.64(16.9)$ & $459.64(16.9)$ \\
Forest plantation & $1176.60(43.2)$ & $1176.60(43.2)$ & $1156.60(42.5)$ & $876.7(32.2)$ & $798.9(29.4)$ \\
Pasture and scrubland & $191.75(7.0)$ & $139.85(5.1)$ & $139.85(5.1)$ & $139.85(5.1)$ & $139.85(5.1)$ \\
Meadows and farmland & $524.51(19.3)$ & $576.41(21.2)$ & $596.41(21.9)$ & $576.41(21.2)$ & $576.41(21.2)$ \\
Urban land & $77.71(2.9)$ & $77.71(2.9)$ & $77.71(2.9)$ & $77.71(2.9)$ & $77.71(2.9)$ \\
Total & $2720.47(100.0)$ & $2720.47(100.0)$ & $2720.47(100.0)$ & $2720.47(100.0)$ & $2720.47(100.0)$ \\
\hline \multicolumn{3}{c}{ Source: adapted from [55]. } & &
\end{tabular}

On the other hand, Table 4 shows the impact matrix of the case studied, where the assessment received by each alternative in each of the different criteria is shown.

Table 4. Impact matrix for the case of Mutriku.

\begin{tabular}{|c|c|c|c|c|c|c|c|c|}
\hline \multirow{3}{*}{ Dimensions } & \multirow{3}{*}{ Criteria } & \multirow{3}{*}{$\begin{array}{c}\text { Unit of } \\
\text { Measurement }\end{array}$} & \multirow{3}{*}{ Trend } & \multicolumn{5}{|c|}{ Alternatives } \\
\hline & & & & \multirow{2}{*}{$\begin{array}{c}\text { Business } \\
\text { As Usual } \\
\text { A1 }\end{array}$} & \multicolumn{2}{|c|}{$\begin{array}{c}\text { Promote New Agricultural } \\
\text { Activities }\end{array}$} & \multicolumn{2}{|c|}{$\begin{array}{l}\text { Promote Native } \\
\text { Species Forests }\end{array}$} \\
\hline & & & & & A 2a & A $2 b$ & A 3a & A $3 b$ \\
\hline \multirow{2}{*}{ Ecological } & Biodiversity & Index & Max & 245,383 & 246,732 & 247,992 & 268,025 & 273,549 \\
\hline & Landscape & Index & Max & $3,387,206$ & $3,392,183$ & $3,397,733$ & $3,774,555$ & $3,873,750$ \\
\hline \multirow{2}{*}{ Economic } & $\begin{array}{l}\text { Agricultural } \\
\text { income }\end{array}$ & $€$ & Max & $367,028 €$ & $459,295 €$ & $461,120 €$ & $440,515 €$ & $435,643 €$ \\
\hline & Public cost & $€$ & Min & $379,429 €$ & $416,259 €$ & $426,565 €$ & $561,801 €$ & $599,444 €$ \\
\hline \multirow[t]{2}{*}{ Social } & $\begin{array}{c}\text { Local } \\
\text { consumption }\end{array}$ & Qualitative & Max & $\begin{array}{l}\text { Quite } \\
\text { bad }\end{array}$ & Quite good & Good & $\begin{array}{l}\text { Quite } \\
\text { good }\end{array}$ & $\begin{array}{l}\text { Quite } \\
\text { good }\end{array}$ \\
\hline & $\begin{array}{l}\text { Attachment } \\
\text { to the land }\end{array}$ & Qualitative & Max & Average & Good & Good & Bad & Bad \\
\hline
\end{tabular}


The results of the assessment carried out in the case of Mutriku show that the best ranked alternatives according to the criteria used are A2b ("C" in Figure A2 in Appendix A) and A3b ("E"), while the worst ranked alternative is A1 ("A"). Among the first ones (A2b and A3b), it is not possible to say that one of the two alternatives is more favorable than the other, they are incomparable between each other since they show the same degree of suitability. Technically, incomparability is a particular case arising from the intersection between the pre-ordering of degrees of preference (column $\phi+$ in Figure A2 in Appendix A) and degrees of rejection (column ф-) [47,62]. This incomparability lies in the fact that, while sharing certain requirements for consideration in the assessment, the two alternatives have characteristics of a different nature.

In addition, the social evaluation carried out in this case shows that, among the most technically adequate alternatives, the $\mathrm{A} 3 \mathrm{~b}$ is preferred by a wide number of actors, a group that comprises the most environmentalist positions of the public administrations, the technicians working in rural development, as well as the different social groups and associations. However, it is the least valued alternative for another group of actors, the one formed by the landowners, the traditional farmers, and the traditional positions of the provincial public administration. A3b, being one of the most technically suitable alternatives, presents a high degree of social conflict due to the conflicting opinions that exist in society regarding forest policy.

\subsection{Methodology}

Upon those case studies, an analysis of different degrees of sustainability has been carried out. Parameters of the model have been modified, affecting the compensability and substitutability of the valuations in the different criteria, with the aim of placing the model before the paradigms of strong sustainability or weak sustainability. Three types of modifications have been introduced in NAIADE to observe its behavior: (i) on the degree of compensation between criteria (parameter $\gamma$ ); (ii) on the credibility index (parameter $\alpha$ ); (iii) on the thresholds of preference and indifference between criteria scores. In addition, (iv), a trade-off analysis has also been carried out through NAIADE by comparing alternatives by criteria. The first two analyses have been carried out jointly to facilitate understanding. The modification of the parameters $\gamma$ and $\alpha$ has been a recurrent technique for sensitivity analysis in numerous empirical works [66-71].

(i) Variations in the compensation index (parameter $\gamma$ ) and the credibility index (parameter $\alpha$ )

The parameter $\gamma$ establishes the level of compensation between valuations obtained by the same alternative on different criteria [62]. Compensation means that positive valuation obtained on certain criteria can be offset by negative valuation on other criteria. This parameter obtains values between 0 and 1. A low value of $\gamma$ allows the compensation between valuations, placing the model in the framework of the weak sustainability. Conversely, a high value of $\gamma$ indicates that the valuations do not offset each other, placing the model in the strong sustainability framework.

On the other hand, the parameter $\alpha$ reflects the uncertainty of the model. The parameter $\alpha$ increases or relaxes the minimum difference required for the criteria assessments to be considered in the aggregation process, i.e., it establishes a greater or lesser intensity of preference or distance between assessments [62]. This parameter affects all criteria simultaneously, relaxing or tightening the intensities of preference.

(ii) Variations in preference and indifference thresholds

Variation of preference and indifference thresholds is another method for testing model robustness [70-72]. The thresholds are set for each criterion, and they mark the minimum differences between valuations for an alternative to be ranked in different positions of suitability, that is, they set the differences in valuations that an alternative must obtain in a criterion in order to be considered much better, better, equal, worse, or much worse than another. The thresholds for the qualitative criteria are set by default in the NAIADE aggregation process. The thresholds of the quantitative criteria, however, 
are fixed through the technical work of the analysts, and must reflect the positions shown by the social actors in the participatory process, this being one of the most delicate aspects of the evaluation, because of the subjectivity and responsibility that it entails [73]. To minimize this subjectivity, authors such as Vallejo et al. [71] define the thresholds based on the maximum and minimum values obtained by the alternatives for each criterion. Otherwise, the thresholds are reduced or increased by $50 \%$ to observe the effect of these variations on the results [70].

(iii) Trade-off analysis

As a complement to the previous analyses, the best ranked alternatives in each case study have been compared with respect to the evaluation criteria. This analysis allows us to observe the differences between the alternatives with respect to each criterion, which makes it possible to know in each alternative the valuations by criteria in terms of trade-off. This analysis is interesting in terms of sustainability in that if the criteria are perceived as proxy of the various types of capital, i.e., natural capital vs. manufactured capital, it shows the potential trade-offs or substitutability between them.

\section{Analysis and Results}

\subsection{Sustainability Analysis of Case Study 1: GSB}

(i) Variations of the parameter $\gamma$ and of the parameter $\alpha$

For this analysis, the model was first tested giving different values to $\gamma$. According to the objective pursued, the parameter has been varied from $\gamma=0.1$ (alignment with weak sustainability) to $\gamma=0.9$ (alignment with strong sustainability), keeping constant $\alpha=0.5$. It can be seen that the result does not vary significantly with these variations, so the greater or lesser degree of compensation does not have a determining influence (see Table A1 in Appendix B).

On the other hand, it has also been verified that, given the values of the credibility index of $\alpha=0.3, \alpha=0.5$, and $\alpha=0.7$, the result does not vary significantly and, alternatively, A32 remains first in the ranking (Table A1 in Appendix B). For any value of $\gamma$, if we reduce the minimum difference between scores required to consider different two alternatives, that is, when we reduce to $\alpha=0.3$, the intersection shows that alternative A32 is still more suitable. However, if $\alpha$ increases to $\alpha=0.7$, the minimum differences required between valuations to consider two different alternatives are relaxed by cancelling the effect of the small differences, and in this case, the model places several alternatives, A42, A32, A31, and A22 in the first place of the ranking, not being able to establish a preference between them. In terms of natural capital, A42 is the most valuable alternative, followed by A32 and A31, and lastly A22.

(ii) Variations in preference and indifference thresholds

Based on the preference thresholds established in the case study (Table 5), this analysis has proceeded in two directions. Firstly, the thresholds initially established have been extended by $30 \%$, requiring greater differences in order to consider the assessments of the alternatives differently, and secondly, the thresholds have been reduced by $30 \%$ in accordance with the reduction proposed by Vallejo et al. [71]. By reducing the thresholds, the result does not change, and the best rated alternative remains A32 followed by A42. However, if we increase the thresholds, the best rated alternative remains $\mathrm{A} 32$ but $\mathrm{A} 42, \mathrm{~A} 32$, and $\mathrm{A} 22$ are placed in second place, coinciding with what was obtained by setting $\alpha=0.7$. 
Table 5. Criteria preference thresholds for GSB.

\begin{tabular}{cccccc}
\hline & \multicolumn{3}{c}{ Preference Thresholds } \\
\hline Criterion & Indicator & $\begin{array}{c}\text { Much Better }(\geq) ; \\
\text { Much Worse }(\leq)\end{array}$ & $\begin{array}{c}\text { Better }(>) ; \\
\text { Worse }(<)\end{array}$ & $\begin{array}{c}\text { Almost the } \\
\text { Same }(\sim=)\end{array}$ & $\begin{array}{c}\text { Same } \\
(=)\end{array}$ \\
\hline Landscape & Index & 3000 & 2000 & 1000 & 100 \\
\hline Biodiversity & Index & 40 & 30 & 10 & 0 \\
\hline Recreational value & Million $€$ & 2 & 1 & 0.5 & 0 \\
\hline Social welfare & Million $€$ & 140 & 100 & 50 & 0 \\
\hline Public cost & $€$ & 10,000 & 6000 & 3000 & 0 \\
\hline Income generation & $€$ & 10,000 & 7000 & 4000 & 2000 \\
\hline Agricultural activity & Qualitative & $\geq ; \leq 0.375$ & $>;<0.6$ & $\sim=0.32$ & $=0.0$ \\
\hline Acceptance & Qualitative & $\geq ; \leq 0.375$ & $>;<0.6$ & $\sim=0.32$ & $=0.0$ \\
\hline \multicolumn{2}{c}{ Source: adapted from $[55]}$. & &
\end{tabular}

Finally, for a more complete analysis, the thresholds of the ecological criteria, i.e., landscape and biodiversity, have been reduced. The aim is to observe the effect on the result of any minimal variation in the valuation of these criteria. By reducing the preference thresholds of these criteria by $50 \%$, we achieve a greater effect of any minimum difference in their valuations, and therefore, their final effect on the result increases. Given these variations, the ranking of alternatives does not vary significantly in this case, with the best ranked alternative being A32, and the second A42.

\section{(iii) Trade-off analysis}

In the two best evaluated alternatives (A32 and A42), a change in land use is proposed, increasing the areas dedicated to different native species to the detriment of forest plantations. Additional aid to that currently approved for the promotion of these native species is also envisaged. If these two alternatives are compared, it can be seen that alternative A32, the best rated, obtains better ratings in the criteria of recreational and cultural value, cost, agricultural activity, and social acceptance, while A42, however, obtains better ratings in landscape, biodiversity, and social welfare (Figure A3 in Appendix A), being consistent with the greater presence of natural capital in this last alternative.

\subsection{Sustainability Analysis of Case Study 2: Mutriku Municipality}

(i) Variations of the parameter $\gamma$ and of the parameter $\alpha$

In the event of variations in the compensation index $\gamma=0.1, \gamma=0.5$, and $\gamma=0.9$, and keeping constant $\alpha=0.5$, neither the rankings of the alternatives nor their intersection varies significantly, and alternatives A2b and A3b remain the most suitable (Table A2 in Appendix B). Therefore, the degree of compensation is not decisive in the final result, and therefore no alignment with respect to weak/strong sustainability is observed. Similarly, the behavior of the model is observed by giving different values to the parameter $\alpha$ (Table A2 in Appendix B), seeing that the result does not vary significantly, with alternatives $\mathrm{A} 2 \mathrm{~b}$ and $\mathrm{A} 3 \mathrm{~b}$ being the first in the ranking.

On the other hand, for any value of $\gamma$, when the minimum difference between valuations required to consider different two alternatives is relaxed, that is, when less differences are considered sufficient $(\alpha=0.3)$, the intersection shows that alternative A3b, the one with the highest ecological value by means of maximum potentiation of native forests (high natural capital), is shown to be the most appropriate. On the contrary, if $\alpha$ increases $(\alpha=0.7)$ and the minimum differences are no longer a determining factor in the final ranking, the intersection shows that alternative A2b, which proposes a more humanized rural environment through maximum agricultural empowerment, i.e., with fewer natural capital than $\mathrm{A} 3 \mathrm{~b}$, is the most appropriate. 
(ii) Variations in preference and indifference thresholds

From the preference thresholds defined in this case (Table 6), as in the previous case, we have proceeded in two directions. On the one hand, the preference thresholds have been increased by $30 \%$ and, on the other, they have been reduced by $30 \%$ as proposed by Vallejo et al. [71] in order to observe the effect of these variations on the result.

Table 6. Criteria preference thresholds in the case of Mutriku.

\begin{tabular}{cccccc}
\hline & \multicolumn{5}{c}{ Preference Thresholds } \\
\hline Criterion & Indicator & $\begin{array}{c}\text { Much Better ( } \geq \text { ); } \\
\text { Much Worse ( } \leq)\end{array}$ & $\begin{array}{c}\text { Better (>); } \\
\text { Worse (<) }\end{array}$ & $\begin{array}{c}\text { Almost the } \\
\text { Same }(\sim)\end{array}$ & $\begin{array}{c}\text { Same } \\
(=)\end{array}$ \\
\hline Biodiversity & Index & 8000 & 5000 & 4000 & 1000 \\
\hline Landscape & Index & 10,000 & 6000 & 4000 & 400 \\
\hline Profitability & $€$ & 40,000 & 25,000 & 15,000 & 1000 \\
\hline Public cost & $€$ & 70,000 & 50,000 & 25,000 & 5000 \\
\hline Local consumption & Qualitative & $\geq ; \leq 0.375$ & $>;<0.6$ & $\sim=0.32$ & $=0.0$ \\
\hline Attachment to the land & Qualitative & $\geq ; \leq 0.375$ & $>;<0.6$ & $\sim=0.32$ & $=0.0$ \\
\hline & & Source: adapted from $[55]$. & &
\end{tabular}

When faced with threshold extensions, alternative A2b is shown to be the most appropriate in most cases. This result coincides with the one obtained when modifying $\alpha=0.7$ (keeping the preference thresholds unchanged). When faced with reductions in the thresholds, the results obtained indicate that alternative $\mathrm{A} 3 \mathrm{~b}$ is the most suitable, and alternatives $\mathrm{A} 2 \mathrm{a}, \mathrm{A} 2 \mathrm{~b}$, and $\mathrm{A} 3 \mathrm{a}$ are in second place. That is, by reducing the difference requirement for considering different alternatives, the A3b alternative is the most suitable. This result coincides with that obtained by lowering the credibility index to $\alpha=0.3$ (keeping the preference thresholds unchanged).

Finally, as in the previous case study, the preference thresholds of the criteria reflecting the ecological dimension, biodiversity and landscape have been modified, reducing them by 50\% (keeping the preference thresholds of the other criteria constant). In this way, any minimal variation in the valuation of these criteria is considered relevant, and takes on greater weight in the result. In this case, it can be seen that the A3b alternative, the one with the highest ecological value, appears better positioned in the final ranking of alternatives.

\section{(iii) Trade-off analysis}

If we compare alternatives $\mathrm{A} 2 \mathrm{~b}$ and $\mathrm{A} 3 \mathrm{~b}$ by criteria, we see that certain criteria act as trade-offs in the opposite direction in each of them (Figure A4 in Appendix A). The A2b alternative, which proposes the maximum potentiation of new agricultural models while maintaining the current forestry policy, obtains better valuations in the criteria of attachment to the rural land and public cost, and much worse valuations in biodiversity and landscape, respectively. At the same time, the A3b alternative, which proposes a change in forestry policy towards the promotion of native species to the detriment of forest plantations, obtains better evaluations in the criteria of biodiversity and landscape, and worse in attachment to the rural land and public cost, due to the aid proposed for the change in the forestry model.

\subsection{Overall Results}

From the analyses made and their relationship with the degree of sustainability, we obtain the following results.

Firstly, with regard to variations of the parameter $\gamma$ and keeping $\alpha=0.5$, the result remains unchanged in both cases. In the first case, alternative A32 is the best valued, followed by A42. In the case of Mutriku, the A2b and A3b alternatives are the most suitable, although they are incomparable. This means that the variations of $\gamma$, i.e., the degree of substitutability does not influence the result. 
Therefore, the compensation index does not determine the alignment of the case studies models with respect to weak/strong sustainability. Secondly, given the simultaneous variations of $\gamma$ and $\alpha$, we conclude that the determining parameter is $\alpha$ and not so much $\gamma$. In fact, for any value of $\gamma$ and if it increases $\alpha$, in the case of GSB, four of the alternatives assessed, A22, A31, A32, and A42, occupy the first place in the ranking, and in the case of Mutriku, alternative $A 2 b$ is presented as the most suitable. Thirdly, it should be noted that these same results coincide with those achieved in the case of GSB in the face of variations in the preference thresholds. In the case of Mutriku, when increasing the thresholds, the most suitable alternative is $A 2 b$, i.e., the same result as when increasing $\alpha$. Similarly, lowering preference thresholds, the A3b is the most suitable alternative, i.e., the same result as lowering $\alpha$.

A high value of $\alpha$, therefore, means an increase in the preference thresholds, the model is more insensitive to small differences between the valuations, and fewer criteria are considered in the aggregation process. Similarly, with the reduction of $\alpha$, small differences in the valuations have a decisive effect on the outcome of the model, and a greater number of criteria are considered in the aggregation process. In the case of GSB, when $\alpha$ increases, four alternatives are at the top of the ranking, all of which advocate different intensities of ecological value enhancement. In the case of Mutriku, in view of an increase in $\alpha$, the A2b alternative, which obtains better ratings in the economic and social dimensions, emerges as the best valued. This result could be aligned with the weak sustainability paradigm, given that the best valuations of alternatives that propose greater manufactured capital could hypothetically compensate for natural capital decreases. On the other hand, when $\alpha$ is reduced, it may be the case of an enhancement of natural capital as: in GSB, the best ranked is A32, an alternative that poses a high ecological value (high natural capital), and in Mutriku, the best ranked is A3b, an alternative that poses a higher natural capital than A2b.

\section{Discussion}

The sustainability analyses carried out in this study allow us to go deeper into the degree of sustainability achieved, or even determine the conditions assumed either by strong sustainability and weak sustainability paradigms.

The general approach to address weak/strong sustainability issue has traditionally focused on substitutability and compensability, and it has been the case in diverse applications (see [1]). Particularly within MCDA context, the use of compensatory and non-compensatory methods has also been deeply discussed in terms of outcomes achieved [51,60], and they have been respectively linked to weak and strong sustainability paradigms $[23,24]$. By means of the two case studies, we have tried to go further, adding to the analysis the performance of the model when varying particular parameters beyond compensability (credibility index, preference, and indifference thresholds), and comparing alternatives in a trade-off view.

From the results of our analysis, it can be deduced that in addition to the general approach to address strong and weak sustainability according to the degree of compensation between natural capital and manufactured capital, the setting of preference thresholds and the number of preference relations considered can also be considered as determining factors. In other words, the sensitivity of the model to small differences between valuations and the inclusion of all criteria are key to determine weak and strong sustainability approaches. In this regard, on the one hand, some authors do not link the credibility index (parameter $\alpha$ ) with sustainability, but only with the uncertainty of the model, since it influences the intensity of preference [66,67]. On the other hand, Shmelev and Rodríguez-Labajos [68] interpret a high $\alpha$ as strong sustainability to the extent that a lower degree of compensation among criteria is allowed, and vice versa. However, the variations in $\alpha$ do affect the defined preference thresholds, relaxing the model by considering only criteria where there are large differences between alternatives (increase in $\alpha$ ) or making it stricter (decrease in $\alpha$ ), but they act on all the criteria simultaneously without knowing exactly their effect on each of them. Therefore, the variations in the preference thresholds of each criterion allow us to face the sustainability analysis with greater guarantees. 
In both case studies, the lower value we give to $\alpha$ or the lower preference thresholds we establish, i.e., the more sensitive the model is to small differences between valuations, the best ranked alternatives are that propose high natural capital. Similarly, the higher values of $\alpha$ or wider preference thresholds, alternatives with high manufactured capital are in the top positions of the ranking. Therefore, the more sensitive or strict in terms of small differences the models are, the larger the natural capital alternatives are projected to be, i.e., the alternatives that propose an increase in the area of native forests and a reduction in forest plantations. These alternatives, in turn, would be in a position to provide greater ecological values and ecosystem services. Thus, these results would be aligned with strong sustainability, all the more so as this natural capital would not be replaced by the manufactured capital in the future. It is reasonable to think that the natural capital will not be replaced in protected areas such as N2000; in particular, GSB is included in N2000, and an important part of Mutriku municipality is so.

Additionally, the definition of critical thresholds of diverse dimensions is also a key prerequisite to approach strong sustainability $[20,21]$. In fact, in our analysis, the establishment of the critical natural capital threshold is an underlying issue. For example, in the case of Mutriku, the reduction of the preference thresholds of the ecological criteria (i.e., biodiversity and landscape), which gives greater importance to minimal differences in the valuations of these criteria, makes the effect of these criteria on the result greater, increasing their weight in the result. In fact, if we reduce the thresholds of the biodiversity and landscape criteria while keeping the thresholds of the other criteria constant, alternative $\mathrm{A} 3 \mathrm{~b}$, the one with the highest ecological value, is better positioned in the overall ranking. This highlights the possibility of establishing critical natural capital thresholds for the criteria that reflect the ecological dimension, which, however, should be established for each specific case given the multiple complex interrelations that exist in socio-ecological systems.

\section{Conclusions}

A procedure has been developed to assess the response of multi-criteria models to the strong and weak sustainability paradigms by performing a sustainability analysis. The development of this analysis in the two case studies has, in turn, highlighted the validity and possibilities offered by the NAIADE aggregation method for such analysis. In addition, to our knowledge, there is no application of SMCE that addresses the weak vs. strong sustainability issue in depth, so this analysis carried out on two case studies aims to contribute to this debate, both methodologically and conceptually.

The analysis has shown that sustainability in rural land use planning is a concept that goes beyond the possible trade-off between different types of capital. On the one hand, the analysis carried out has shown that the substitutability or non-substitutability of different types of capital is not the only issue that determines the degree of sustainability of a model. On the other hand, from the sustainability analysis, it can be deduced that the establishment of the credibility index $(\alpha)$, the thresholds, and the preference intensities are factors that determine the sensitivity of the model to small variations and the inclusion or not of all the criteria, influencing the alignment of the models within the framework of the strong sustainability or weak sustainability. However, the variations on $\alpha$ act on all criteria simultaneously without the exact effect on each of them being known. For this reason, the variations of the preference thresholds offer a greater guarantee for the sustainability analysis, providing insight about the exact effect of the variations of the preference thresholds of each criterion on the final result.

Author Contributions: Conceptualization, methodology, software, validation, formal analysis, investigation, resources, data curation, writing-original draft preparation, writing-review and editing, visualization, supervision, project administration and funding acquisition: I.B.-R. and I.E. All authors have read and agreed to the published version of the manuscript.

Funding: This research has received funding from EKOPOL Research Group (Basque Government-UPV/EHUIT-1365-19).

Acknowledgments: We would like to acknowledge Oihana García and two anonymous reviewers for their valuable comments on previous versions of this paper. 
Conflicts of Interest: The authors declare no conflict of interest.

\section{Appendix A}

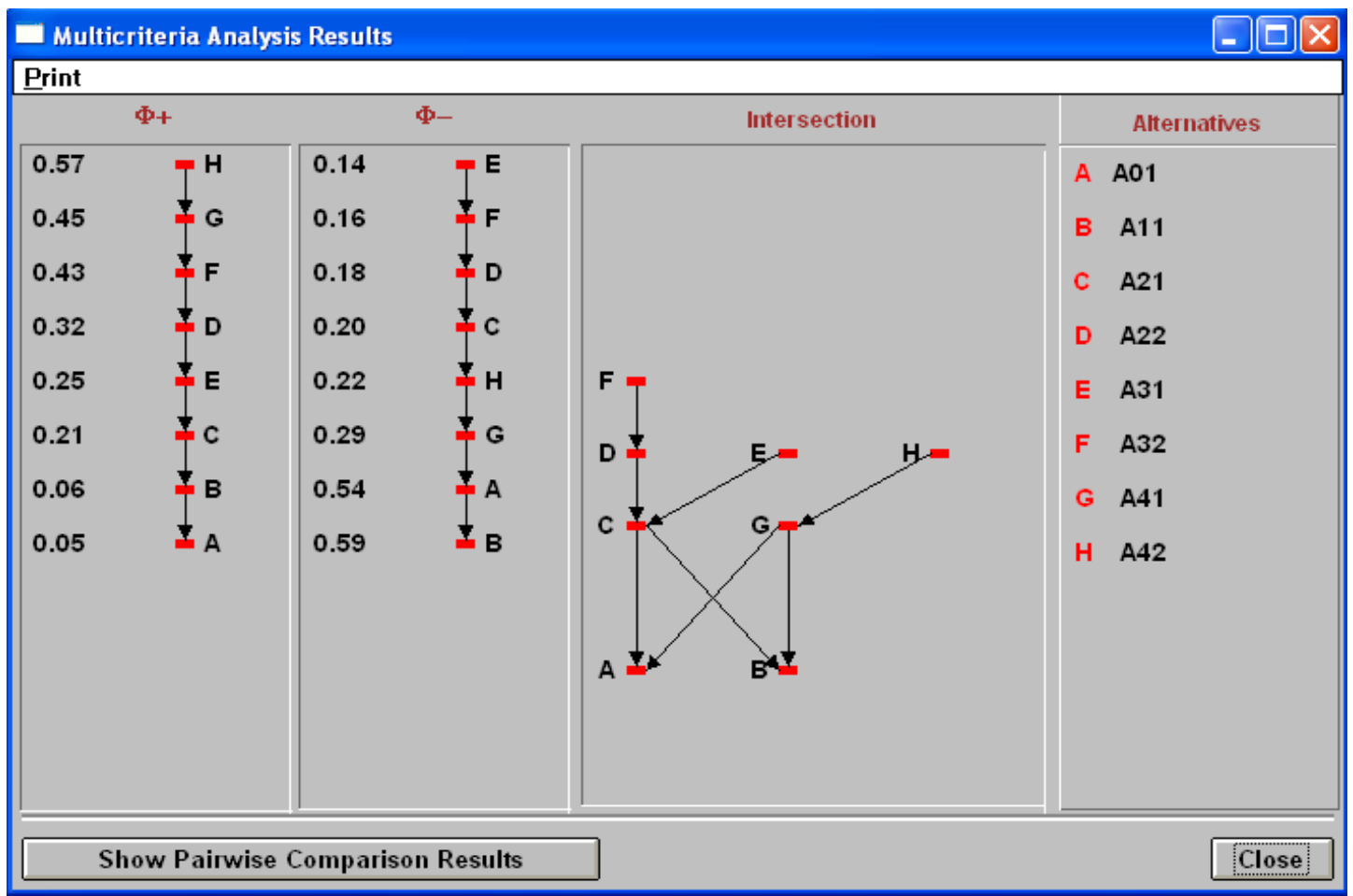

Figure A1. Indexes $\phi+$ and $\phi$-and their intersection in the case of GSB.

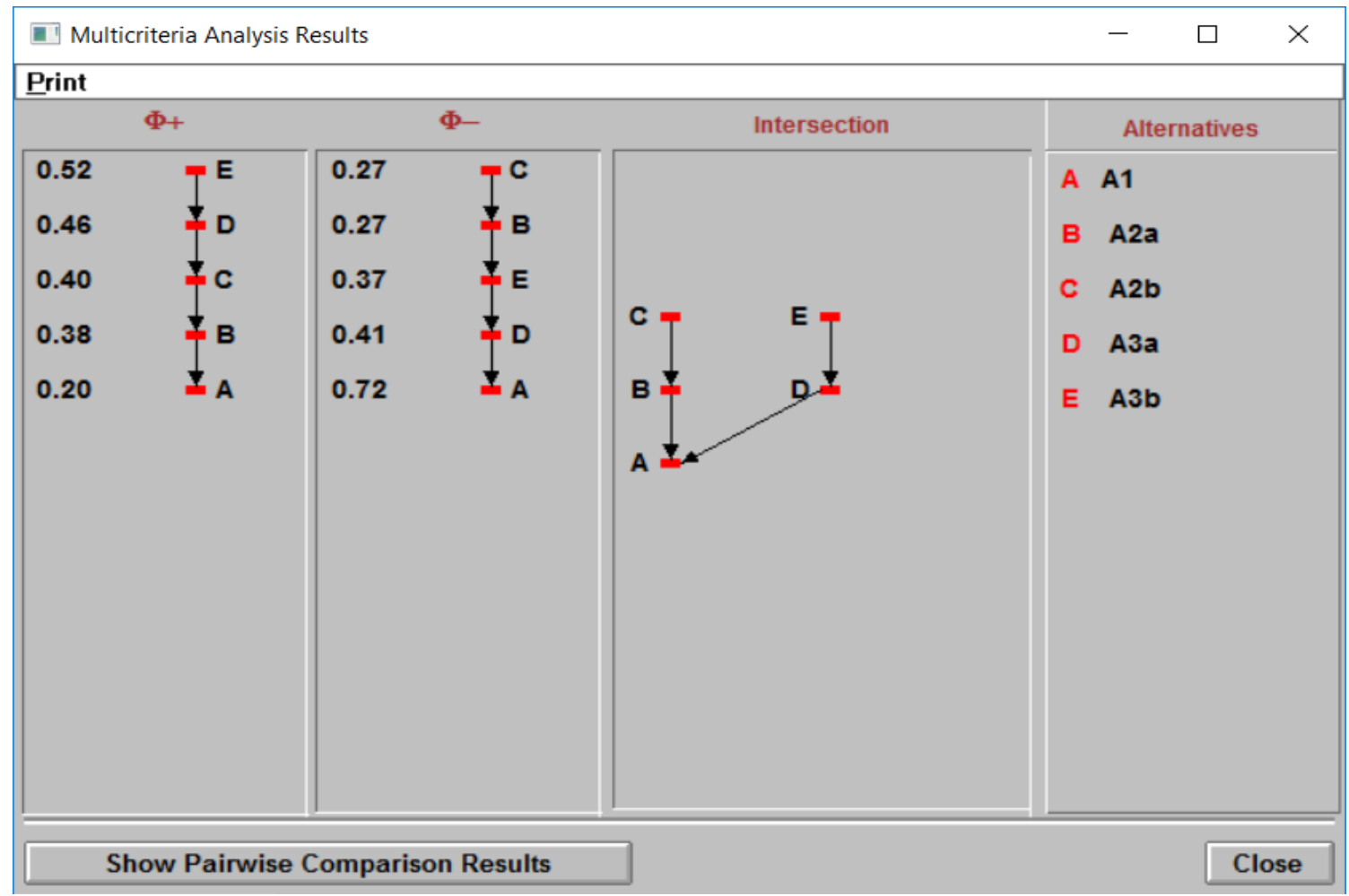

Figure A2. Indexes $\phi+$ and $\phi-$ and their intersection in the case of Mutriku. 


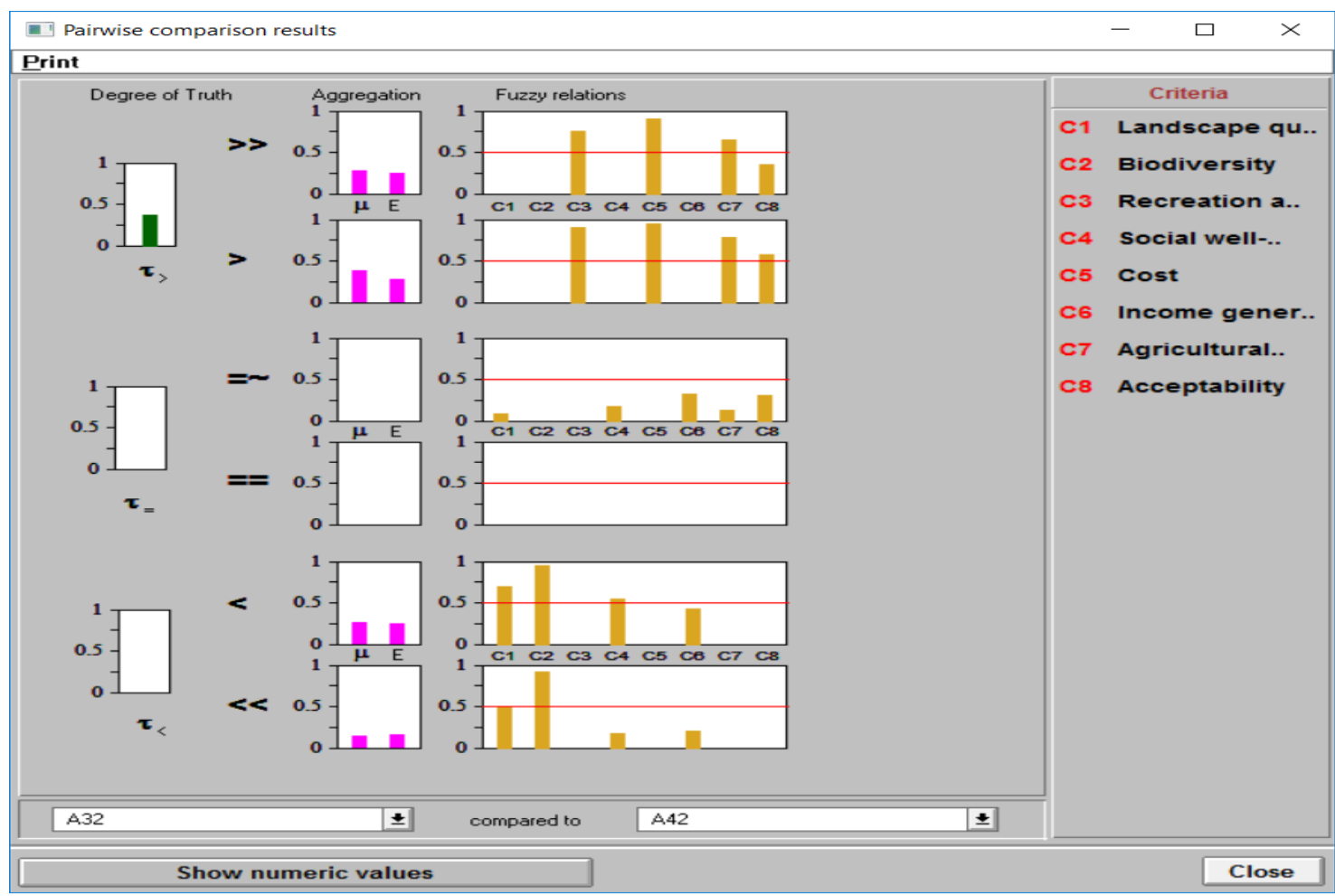

Figure A3. Comparison between A32 and A42 by evaluation criteria in the case of GSB.

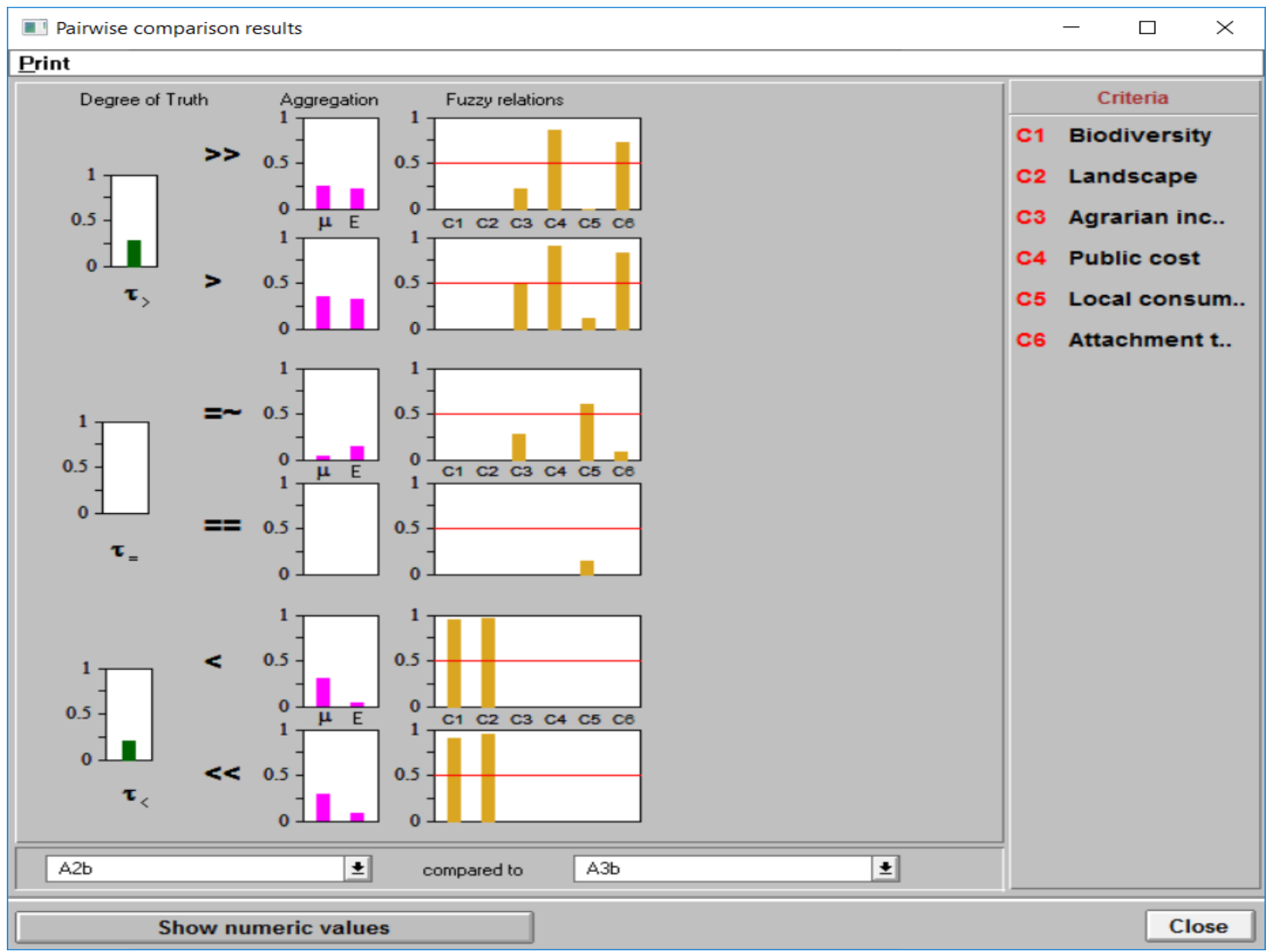

Figure A4. Comparison of $\mathrm{A} 2 \mathrm{~b}$ and $\mathrm{A} 3 \mathrm{~b}$ by criteria in the case of Mutriku. 


\section{Appendix B}

Table A1. Sustainability analysis: variations of $\gamma$ and $\alpha$ in the case of GSB.

\begin{tabular}{|c|c|c|c|c|c|c|c|c|c|}
\hline & \multicolumn{3}{|c|}{$\alpha=0.3$} & \multicolumn{3}{|c|}{$\alpha=0.5$} & \multicolumn{3}{|c|}{$\alpha=0.7$} \\
\hline & $\phi+$ & ф- & Ranking & $\phi+$ & ф- & Ranking & $\phi+$ & ф- & Ranking \\
\hline$\gamma=0.1$ & $\begin{array}{l}\text { A42 } \\
\text { A32 } \\
\text { A22 } \\
\text { A41 } \\
\text { A31 } \\
\text { A21 } \\
\text { A11 } \\
\text { A01 } \\
\end{array}$ & $\begin{array}{l}\text { A32 } \\
\text { A21 } \\
\text { A22 }\end{array}$ & $\begin{array}{l}\text { 1st-A32 } \\
\text { 2nd-A42 } \\
\text { 3rd-A22 } \\
\text { 4th-A31 } \\
\text { 4th-A21 } \\
\text { 4th-A41 } \\
\text { 5th-A11 } \\
\text { 6th-A01 }\end{array}$ & $\begin{array}{l}\text { A42 } \\
\text { A32 } \\
\text { A22 } \\
\text { A41 } \\
\text { A31 } \\
\text { A21 } \\
\text { A11 } \\
\text { A01 } \\
\end{array}$ & $\begin{array}{l}\text { A32 } \\
\text { A31 } \\
\text { A22 } \\
\text { A21 } \\
\text { A42 } \\
\text { A41 } \\
\text { A11 } \\
\text { A01 } \\
\end{array}$ & $\begin{array}{l}\text { 1st-A32 } \\
\text { 2nd-A22 } \\
\text { 3rd-A42 } \\
\text { 3rd-A31 } \\
\text { 4th-A21 } \\
\text { 4th-A41 } \\
\text { 5th-A11 } \\
\text { 6th-A01 }\end{array}$ & $\begin{array}{l}\text { A42 } \\
\text { A32 } \\
\text { A22 } \\
\text { A41 } \\
\text { A31 } \\
\text { A21 } \\
\text { A11 } \\
\text { A01 } \\
\end{array}$ & $\begin{array}{l}\text { A31 } \\
\text { A21 } \\
\text { A32 }\end{array}$ & $\begin{array}{l}\text { 1st-A32 } \\
\text { 2nd-A42 } \\
\text { 2nd-A31 } \\
\text { 2nd-A22 } \\
\text { 3rd-A21 } \\
\text { 3rd-A41 } \\
\text { 4th-A11 } \\
\text { 5th-A01 }\end{array}$ \\
\hline$\gamma=0.5$ & $\begin{array}{l}\text { A42 } \\
\text { A32 } \\
\text { A22 } \\
\text { A41 } \\
\text { A31 } \\
\text { A21 } \\
\text { A11 } \\
\text { A01 }\end{array}$ & $\begin{array}{l}\text { A32 } \\
\text { A21 } \\
\text { A31 } \\
\text { A22 } \\
\text { A42 } \\
\text { A11 } \\
\text { A41 } \\
\text { A01 }\end{array}$ & $\begin{array}{l}\text { 1st-A32 } \\
\text { 2nd-A42 } \\
\text { 2nd-A22 } \\
\text { 3rd-A31 } \\
\text { 3rd-A21 } \\
\text { 4th-A41 } \\
\text { 4th-A11 } \\
\text { 5th-A01 }\end{array}$ & $\begin{array}{l}\text { A42 } \\
\text { A32 } \\
\text { A22 } \\
\text { A41 } \\
\text { A31 } \\
\text { A21 } \\
\text { A11 } \\
\text { A01 }\end{array}$ & $\begin{array}{l}\text { A31 } \\
\text { A21 } \\
\text { A32 } \\
\text { A22 } \\
\text { A42 } \\
\text { A41 } \\
\text { A11 } \\
\text { A01 }\end{array}$ & $\begin{array}{l}\text { 1st-A32 } \\
\text { 2nd-A42 } \\
\text { 2nd-A22 } \\
\text { 2nd-A31 } \\
\text { 3rd-A21 } \\
\text { 3rd-A41 } \\
\text { 4th-A11 } \\
\text { 5th-A01 }\end{array}$ & $\begin{array}{l}\text { A42 } \\
\text { A32 } \\
\text { A22 } \\
\text { A41 } \\
\text { A31 } \\
\text { A21 } \\
\text { A11 } \\
\text { A01 }\end{array}$ & $\begin{array}{l}\text { A31 } \\
\text { A21 } \\
\text { A22 } \\
\text { A32 }\end{array}$ & $\begin{array}{l}\text { 1st-A42 } \\
\text { 1st-A32 } \\
\text { 1st-A31 } \\
\text { 1st-A22 } \\
\text { 2nd-A21 } \\
\text { 2nd-A41 } \\
\text { 3rd-A11 } \\
\text { 4th-A01 }\end{array}$ \\
\hline$\gamma=0.9$ & $\begin{array}{l}\text { A42 } \\
\text { A32 } \\
\text { A31 } \\
\text { A41 } \\
\text { A22 } \\
\text { A21 } \\
\text { A11 } \\
\text { A01 }\end{array}$ & $\begin{array}{l}\text { A21 } \\
\text { A32 } \\
\text { A31 } \\
\text { A22 } \\
\text { A42 } \\
\text { A11 } \\
\text { A41 } \\
\text { A01 }\end{array}$ & $\begin{array}{l}\text { 1st-A32 } \\
\text { 2nd-A42 } \\
\text { 3rd-A31 } \\
\text { 4th-A21 } \\
\text { 4th-A22 } \\
\text { 5th-A41 } \\
\text { 5th-A11 } \\
\text { 6th-A01 }\end{array}$ & $\begin{array}{l}\text { A42 } \\
\text { A32 } \\
\text { A41 } \\
\text { A22 } \\
\text { A31 } \\
\text { A11 } \\
\text { A21 } \\
\text { A01 }\end{array}$ & $\begin{array}{l}\text { A31 } \\
\text { A21 } \\
\text { A32 } \\
\text { A22 } \\
\text { A11 } \\
\text { A42 } \\
\text { A41 } \\
\text { A01 }\end{array}$ & $\begin{array}{l}\text { 1st-A32 } \\
\text { 2nd-A31 } \\
\text { 3rd-A42 } \\
\text { 3rd-A22 } \\
\text { 4th-A21 } \\
\text { 4th-A41 } \\
\text { 4th-A11 } \\
\text { 5th-A01 }\end{array}$ & $\begin{array}{l}\text { A42 } \\
\text { A41 } \\
\text { A32 } \\
\text { A22 } \\
\text { A11 } \\
\text { A31 } \\
\text { A21 } \\
\text { A01 }\end{array}$ & $\begin{array}{l}\text { A31 } \\
\text { A21 } \\
\text { A22 } \\
\text { A32 } \\
\text { A11 } \\
\text { A42 } \\
\text { A41 } \\
\text { A01 }\end{array}$ & $\begin{array}{l}\text { 1st-A42 } \\
\text { 1st-A32 } \\
\text { 1st-A31 } \\
\text { 1st-A22 } \\
\text { 2nd-A41 } \\
\text { 2nd-A21 } \\
\text { 2nd-A11 } \\
\text { 3rd-A01 }\end{array}$ \\
\hline
\end{tabular}

Source: own elaboration.

Table A2. Sustainability analysis: variations of $\gamma$ and $\alpha$ in the case of Mutriku.

\begin{tabular}{|c|c|c|c|c|c|c|c|c|c|}
\hline & \multicolumn{3}{|c|}{$\alpha=0.3$} & \multicolumn{3}{|c|}{$\alpha=0.5$} & \multicolumn{3}{|c|}{$\alpha=0.7$} \\
\hline & $\phi+$ & ф- & Ranking & $\phi+$ & ф- & Ranking & $\phi+$ & $\phi-$ & Ranking \\
\hline \multirow[t]{5}{*}{$\gamma=0.1$} & $\mathrm{~A} 3 \mathrm{~b}$ & A2a & $1 \mathrm{st}-\mathrm{A} 3 \mathrm{~b}$ & $\mathrm{~A} 3 \mathrm{~b}$ & $\mathrm{~A} 2 \mathrm{~b}$ & 1st-A2b & $\mathrm{A} 3 \mathrm{~b}$ & A3a & 1st-A3a \\
\hline & A3a & $\mathrm{A} 2 \mathrm{~b}$ & $2 n d-A 2 b$ & АЗ & A2a & $1 s t-A 3 b$ & A3a & $\mathrm{A} 2 \mathrm{~b}$ & 2nd-A2b \\
\hline & $A 2 b$ & $\mathrm{~A} 3 \mathrm{~b}$ & 2nd-A2a & $\mathrm{A} 2 \mathrm{~b}$ & A3b & 2nd-A2a & $\mathrm{A} 2 \mathrm{~b}$ & A2a & $3 r d-A 3 b$ \\
\hline & A2a & A3a & 2nd-A3a & $\mathrm{A} 2 \mathrm{a}$ & A3a & 2nd-A3a & A2a & $\mathrm{A} 3 \mathrm{~b}$ & $3 r d-A 2 a$ \\
\hline & A1 & A1 & 3rd-A1 & A1 & A1 & $3 \mathrm{rd}-\mathrm{A} 1$ & A1 & A1 & 4th-A1 \\
\hline \multirow[t]{5}{*}{$\gamma=0.5$} & A3b & A2a & $1 \mathrm{st}-\mathrm{A} 3 \mathrm{~b}$ & A3b & $\mathrm{A} 2 \mathrm{~b}$ & 1 st-A2b & $\mathrm{A} 3 \mathrm{~b}$ & $\mathrm{~A} 2 \mathrm{~b}$ & $1 \mathrm{st}-\mathrm{A} 2 \mathrm{~b}$ \\
\hline & A3a & $\mathrm{A} 2 \mathrm{~b}$ & $2 n d-A 2 b$ & A3a & A2a & $1 s t-A 3 b$ & A3a & A2a & 2nd-A3b \\
\hline & $A 2 b$ & $\mathrm{~A} 3 \mathrm{~b}$ & $2 n d-A 2 a$ & $\mathrm{~A} 2 \mathrm{~b}$ & $\mathrm{~A} 3 \mathrm{~b}$ & 2nd-A2a & $\mathrm{A} 2 \mathrm{~b}$ & - & 2nd-A3a \\
\hline & $\mathrm{A} 2 \mathrm{a}$ & A3a & 2nd-A3a & $\mathrm{A} 2 \mathrm{a}$ & A3a & 2nd-A3a & A2a & - & 2nd-A2a \\
\hline & A1 & A1 & 3rd-A1 & A1 & A1 & $3 \mathrm{rd}-\mathrm{A} 1$ & A1 & - & $3 \mathrm{rd}-\mathrm{A} 1$ \\
\hline \multirow[t]{5}{*}{$\gamma=0.9$} & $\mathrm{~A} 3 \mathrm{~b}$ & $\mathrm{~A} 2 \mathrm{a}$ & 1st-A3b & $\mathrm{A} 3 \mathrm{~b}$ & $\mathrm{~A} 2 \mathrm{~b}$ & 1st-A2b & $\mathrm{A} 3 \mathrm{~b}$ & $\mathrm{~A} 2 \mathrm{~b}$ & $1 \mathrm{st}-\mathrm{A} 2 \mathrm{~b}$ \\
\hline & A3a & $\mathrm{A} 2 \mathrm{~b}$ & $2 n d-A 2 b$ & A3a & $\mathrm{A} 2 \mathrm{a}$ & 1st-A3b & A3a & A2a & 1st-A3b \\
\hline & $\mathrm{A} 2 \mathrm{~b}$ & $\mathrm{~A} 3 \mathrm{~b}$ & 2nd-A2a & $\mathrm{A} 2 \mathrm{~b}$ & - & 2nd-A2a & $\mathrm{A} 2 \mathrm{~b}$ & $\mathrm{~A} 3 \mathrm{~b}$ & $2 n d-A 2 a$ \\
\hline & $\mathrm{A} 2 \mathrm{a}$ & A3a & 2nd-A3a & $\mathrm{A} 2 \mathrm{a}$ & - & 2nd-A3a & A2a & A3.a & 2nd-A3a \\
\hline & A1 & A1 & 3rd-A1 & A1 & - & 3rd-A1 & A1 & A1 & 3rd-A1 \\
\hline
\end{tabular}

Source: own elaboration.

\section{References}

1. Neumayer, E. Weak Versus Strong Sustainability: Exploring the Limits of Two Opposing Paradigms; Edward Elgar Publishing: Cheltenham, UK, 2010.

2. Solow, R.M. Intergenerational equity and exhaustible resources. Rev. Econ. Stud. 1974, 41, 29-45. [CrossRef]

3. Hartwick, J.M. Intergenerational equity and the investing of rents from exhaustible resources. Am. Econ. Rev. 1977, 67, 972-974. 
4. Neumayer, E. Global warming: Discounting is not the issue, but substitutability is. Energy Policy 1999, 27, 33-43. [CrossRef]

5. Beckerman, W. 'Sustainable development': Is it a useful concept? Environ. Values 1994, 3, 191-209. [CrossRef]

6. Pearce, D.W.; Atkinson, G.D. Capital theory and the measurement of sustainable development: An indicator of "weak" sustainability. Ecol. Econ. 1993, 8, 103-108. [CrossRef]

7. Solow, R. An Almost Practical Step Toward Sustainability; RFF Press: New York, NY, USA, 2014; pp. 11-28.

8. Martínez-Alier, J.; Munda, G.; O’Neill, J. Weak comparability of values as a foundation for ecological economics. Ecol. Econ. 1998, 26, 277-286. [CrossRef]

9. Howarth, R.B. Sustainability as opportunity. Land Econ. 1997, 73, 569-579. [CrossRef]

10. Daly, H.E. Steady-state economics: Concepts, questions, policies. Gaia Ecol. Perspect. Sci. Soc. 1992, 1, 333-338. [CrossRef]

11. Daly, H.E. Toward some operational principles of sustainable development. Ecol. Econ. 1990, 2, 1-6. [CrossRef]

12. Daly, H.E.; Cobb, J.B. For the Common Good; Beacon Press: Boston, MA, USA, 1994.

13. Costanza, R.; Daly, H.E. Natural capital and sustainable development. Conserv. Biol. 1992, 6, 37-46. [CrossRef]

14. Pelenc, J.; Ballet, J. Strong sustainability, critical natural capital and the capability approach. Ecol. Econ. 2015, 112, 36-44. [CrossRef]

15. Ekins, P.; Simon, S.; Deutsch, L.; Folke, C.; De Groot, R. A framework for the practical application of the concepts of critical natural capital and strong sustainability. Ecol. Econ. 2003, 44, 165-185. [CrossRef]

16. Barbier, E.B.; Burgess, J.C.; Folke, C. Paradise Lost?: The Ecological Economics of Biodiversity; Routledge: New Yor, NY, USA, 2019.

17. Butchart, S.H.; Walpole, M.; Collen, B.; Van Strien, A.; Scharlemann, J.P.; Almond, R.E.; Baillie, J.E.; Bomhard, B.; Brown, C.; Bruno, J.; et al. Global biodiversity: Indicators of recent declines. Science 2010, 328, 1164-1168. [CrossRef] [PubMed]

18. Rockström, J.; Steffen, W.; Noone, K.; Persson, Å.; Chapin III, F.S.; Lambin, E.F.; Lenton, T.M.; Scheffer, M.; Folke, C.; Schellnhuber, H.J. A safe operating space for humanity. Nature 2009, 461, 472. [CrossRef] [PubMed]

19. Brand, F. Critical natural capital revisited: Ecological resilience and sustainable development. Ecol. Econ. 2009, 68, 605-612. [CrossRef]

20. Garmendia, E.; Prellezo, R.; Murillas, A.; Escapa, M.; Gallastegui, M. Weak and strong sustainability assessment in fisheries. Ecol. Econ. 2010, 70, 96-106. [CrossRef]

21. Dalmas, L.; Geronimi, V.; Noël, J.; Sang, J.T.K. Economic evaluation of urban heritage: An inclusive approach under a sustainability perspective. J. Cult. Herit. 2015, 16, 681-687. [CrossRef]

22. Janeiro, L.; Patel, M.K. Choosing sustainable technologies. Implications of the underlying sustainability paradigm in the decision-making process. J. Clean. Prod. 2015, 105, 438-446. [CrossRef]

23. Rosén, L.; Back, P.; Söderqvist, T.; Norrman, J.; Brinkhoff, P.; Norberg, T.; Volchko, Y.; Norin, M.; Bergknut, M.; Döberl, G. SCORE: A novel multi-criteria decision analysis approach to assessing the sustainability of contaminated land remediation. Sci. Total Environ. 2015, 511, 621-638. [CrossRef]

24. De Mare, G.; Granata, M.F.; Nesticò, A. Weak and strong compensation for the prioritization of public investments: Multidimensional analysis for pools. Sustainability 2015, 7, 16022-16038. [CrossRef]

25. West, P.C. Redesigning planning, governance, and policies to achieve multiple sustainable development goals. One Earth 2019, 1, 303-304. [CrossRef]

26. Cerreta, M.; Monno, V. Making Strategies in Spatial Planning: Knowledge and Values; Springer Science \& Business Media: London, UK, 2010; Volume 9.

27. Garmendia, E.; Gamboa, G. Weighting social preferences in participatory multi-criteria evaluations: A case study on sustainable natural resource management. Ecol. Econ. 2012, 84, 110-120. [CrossRef]

28. Prato, T. Evaluating land use plans under uncertainty. Land Use Policy 2007, 24, 165-174. [CrossRef]

29. Lamorgese, L.; Geneletti, D. Sustainability principles in strategic environmental assessment: A framework for analysis and examples from Italian urban planning. Environ. Impact Assess. Rev. 2013, 42, 116-126. [CrossRef]

30. Aubry, C.; Ramamonjisoa, J.; Dabat, M.; Rakotoarisoa, J.; Rakotondraibe, J.; Rabeharisoa, L. Urban agriculture and land use in cities: An approach with the multi-functionality and sustainability concepts in the case of Antananarivo (Madagascar). Land Use Policy 2012, 29, 429-439. [CrossRef] 
31. Jonsson, B.G.; Svensson, J.; Mikusiński, G.; Manton, M.; Angelstam, P. European Union's last intact forest landscapes are at a value chain crossroad between multiple use and intensified wood production. Forests 2019, 10, 564. [CrossRef]

32. Pinto-Correia, T.; Guiomar, N.; Guerra, C.A.; Carvalho-Ribeiro, S. Assessing the ability of rural areas to fulfil multiple societal demands. Land Use Policy 2016, 53, 86-96. [CrossRef]

33. Rounsevell, M.; Ewert, F.; Reginster, I.; Leemans, R.; Carter, T. Future scenarios of European agricultural land use: II. Projecting changes in cropland and grassland. Agric. Ecosyst. Environ. 2005, 107, 117-135. [CrossRef]

34. Munroe, D.K.; Van Berkel, D.B.; Verburg, P.H.; Olson, J.L. Alternative trajectories of land abandonment: Causes, consequences and research challenges. Curr. Opin. Environ. Sustain. 2013, 5, 471-476. [CrossRef]

35. Verburg, P.H.; Overmars, K.P. Combining top-down and bottom-up dynamics in land use modeling: Exploring the future of abandoned farmlands in Europe with the Dyna-CLUE model. Lands. Ecol. 2009, 24, 1167. [CrossRef]

36. De Groot, R.S.; Wilson, M.A.; Boumans, R.M. A typology for the classification, description and valuation of ecosystem functions, goods and services. Ecol. Econ. 2002, 41, 393-408. [CrossRef]

37. Schulp, C.J.; Nabuurs, G.; Verburg, P.H. Future carbon sequestration in Europe-Effects of land use change. Agric. Ecosyst. Environ. 2008, 127, 251-264. [CrossRef]

38. Pimm, S.L.; Raven, P. Biodiversity: Extinction by numbers. Nature 2000, 403, 843. [CrossRef]

39. Portela, R.; Rademacher, I. A dynamic model of patterns of deforestation and their effect on the ability of the Brazilian Amazonia to provide ecosystem services. Ecol. Model. 2001, 143, 115-146. [CrossRef]

40. Schroter, D.; Cramer, W.; Leemans, R.; Prentice, I.C.; Araujo, M.B.; Arnell, N.W.; Bondeau, A.; Bugmann, H.; Carter, T.R.; Gracia, C.A.; et al. Ecosystem service supply and vulnerability to global change in Europe. Science 2005, 310, 1333-1337. [CrossRef] [PubMed]

41. Rounsevell, M.D.; Pedroli, B.; Erb, K.; Gramberger, M.; Busck, A.G.; Haberl, H.; Kristensen, S.; Kuemmerle, T.; Lavorel, S.; Lindner, M. Challenges for land system science. Land Use Policy 2012, 29, 899-910. [CrossRef]

42. Crossman, N.D.; Bryan, B.A.; De Groot, R.S.; Lin, Y.; Minang, P.A. Land science contributions to ecosystem services. Curr. Opin. Environ. Sustain. 2013, 5, 509-514. [CrossRef]

43. Baumgartner, R.J. Sustainable development goals and the forest sector-A complex relationship. Forests 2019, 10, 152. [CrossRef]

44. Ezquerro, M.; Pardos, M.; Diaz-Balteiro, L. Sustainability in forest management revisited using multi-criteria decision-making techniques. Sustainability 2019, 11, 3645. [CrossRef]

45. Seppelt, R.; Lautenbach, S.; Volk, M. Identifying trade-offs between ecosystem services, land use, and biodiversity: A plea for combining scenario analysis and optimization on different spatial scales. Curr. Opin. Environ. Sustain. 2013, 5, 458-463. [CrossRef]

46. Pearson, L.J.; Park, S.; Harman, B.; Heyenga, S. Sustainable land use scenario framework: Framework and outcomes from peri-urban South-East Queensland, Australia. Landsc. Urban Plann. 2010, 96, 88-97. [CrossRef]

47. Munda, G.; Nijkamp, P.; Rietveld, P. Qualitative multicriteria methods for fuzzy evaluation problems: An illustration of economic-ecological evaluation. Eur. J. Oper. Res. 1995, 82, 79-97. [CrossRef]

48. Munda, G. Social Multi-Criteria Evaluation for a Sustainable Economy; Springer: Heilderberg, Germany, 2008; Volume 17.

49. Langemeyer, J.; Gómez-Baggethun, E.; Haase, D.; Scheuer, S.; Elmqvist, T. Bridging the gap between ecosystem service assessments and land-use planning through Multi-Criteria Decision Analysis (MCDA). Environ. Sci. Policy 2016, 62, 45-56. [CrossRef]

50. Gamper, C.D.; Turcanu, C. On the governmental use of multi-criteria analysis. Ecol. Econ. 2007, 62, $298-307$. [CrossRef]

51. Jeffreys, I. The use of compensatory and non-compensatory multi-criteria analysis for small-scale forestry. Small Scale For. Econ. Manag. Policy 2004, 3, 99-117. [CrossRef]

52. Oikonomou, V.; Dimitrakopoulos, P.G.; Troumbis, A.Y. Incorporating ecosystem function concept in environmental planning and decision making by means of multi-criteria evaluation: The case-study of Kalloni, Lesbos, Greece. Environ. Manag. 2011, 47, 77-92. [CrossRef]

53. Bagheri, M.; Sulaiman, W.; Vaghefi, N. Land use suitability analysis using multi criteria decision analysis method for coastal management and planning: A case study of Malaysia. J. Environ. Sci. Technol. 2012, 5, 364-372. [CrossRef] 
54. Singh, S.J.; Smetschka, B.; Grima, N.; Ringhofer, L.; Petridis, P.; Biely, K. Social multi-criteria evaluation (SMCE) in theory and practice: Introducing the software OPTamos. Soc. Ecol. Work. Pap. 2016, 160, 1-91.

55. Etxano, I.; Garmendia, E.; Pascual, U.; Hoyos, D.; Díez, M.; Cadiñanos, J.A.; Lozano, P.J. A participatory integrated assessment approach for Natura 2000 network sites. Environ. Plan. C Gov. Policy 2015, 33, 1207-1232. [CrossRef]

56. Etxano, I.; Barinaga-Rementeria Zabaleta, I.; García Alonso, O. Conflicting values in rural planning: A multifunctionality approach through social multi-criteria evaluation. Sustainability 2018, 10, 1431. [CrossRef]

57. Munda, G. Social multi-criteria evaluation: Methodological foundations and operational consequences. Eur. J. Oper. Res. 2004, 158, 662-677. [CrossRef]

58. Funtowicz, S.O.; Ravetz, J.R. The worth of a songbird: Ecological economics as a post-normal science. Ecol. Econ. 1994, 10, 197-207. [CrossRef]

59. O'Neill, J. Representing people, representing nature, representing the world. Environ. Plan. C Gov. Policy 2001, 19, 483-500. [CrossRef]

60. Greco, S.; Figueira, J.; Ehrgott, M. Multiple Criteria Decision Analysis; Springer: New York, NY, USA, 2016.

61. Munda, G. Multicriteria Evaluation in a Fuzzy Environment: Theory and Applications in Ecological Economics; Physica-Verlag: Heidelberg, Germany, 1995.

62. Joint Research Centre of the European Commission. NAIADE: Manual and Tutorial; Joint Research Centre: Istra, Italy, 1996.

63. Acosta, M.; Corral, S. Participatory multi-criteria assessment of forest planning policies in conflicting situations: The case of Tenerife. Forests 2015, 6, 3946-3969. [CrossRef]

64. Iojă, I.; Hossu, C.; Niţă, M.; Onose, D.; Badiu, D.; Manolache, S. Indicators for environmental conflict monitoring in Natura 2000 sites. Proc. Environ. Sci. 2016, 32, 4-11. [CrossRef]

65. Ruiz Urrestarazu, E.; Galdos-Urrutia, R. La perdida de los espacios agrarios y la artificialización del suelo y forestacion en España y en el Pais Vasco. Lurralde Investig. Espac. 2013, 36, 121-133.

66. Cavallaro, F.; Ciraolo, L. A multicriteria approach to evaluate wind energy plants on an Italian island. Energy Policy 2005, 33, 235-244. [CrossRef]

67. Benetto, E.; Dujet, C.; Rousseaux, P. Integrating fuzzy multicriteria analysis and uncertainty evaluation in life cycle assessment. Environ. Model. Softw. 2008, 23, 1461-1467. [CrossRef]

68. Shmelev, S.E.; Rodríguez-Labajos, B. Dynamic multidimensional assessment of sustainability at the macro level: The case of Austria. Ecol. Econ. 2009, 68, 2560-2573. [CrossRef]

69. Monterroso, I.; Binimelis, R.; Rodríguez-Labajos, B. New methods for the analysis of invasion processes: Multi-criteria evaluation of the invasion of Hydrilla verticillata in Guatemala. J. Environ. Manag. 2011, 92, 494-507. [CrossRef]

70. Kolinjivadi, V.; Gamboa, G.; Adamowski, J.; Kosoy, N. Capabilities as justice: Analysing the acceptability of payments for ecosystem services (PES) through 'social multi-criteria evaluation'. Ecol. Econ. 2015, 118, 99-113. [CrossRef]

71. Vallejo, M.C.; Burbano, R.; Falconí, F.; Larrea, C. Leaving oil underground in Ecuador: The Yasuní-ITT initiative from a multi-criteria perspective. Ecol. Econ. 2015, 109, 175-185. [CrossRef]

72. Tarrason, D.; Ortiz, O.; Alcaniz, J.M. A multi-criteria evaluation of organic amendments used to transform an unproductive shrubland into a Mediterranean dehesa. J. Environ. Manag. 2007, 82, 446-456. [CrossRef] [PubMed]

73. Russi, D. Social Multicriteria Evaluation and Reneweable Energy Policies. Ph.D. Thesis, Universidad de Barcelona, Bellaterra, Spain, 2007.

(C) 2020 by the authors. Licensee MDPI, Basel, Switzerland. This article is an open access article distributed under the terms and conditions of the Creative Commons Attribution (CC BY) license (http://creativecommons.org/licenses/by/4.0/). 